\title{
Marketing Information System in Citrus Fruit Pricing: A Case Study of Lattakia, Syria
}

\author{
Ing. Haiyan Sulaiman, Ph.D. Student \\ Czech University of Life Sciences Prague, Faculty of Tropical AgriSciences \\ Email:sulaiman@ftz.czu.cz, \\ Dipl.Kfm. Tomas Hes, Ph.D. \\ Czech University of Life Sciences Prague, Faculty of Tropical AgriSciences \\ Email:hest@ftz.czu.cz \\ Ing. Alexander Kandakov, Ph.D \\ Czech University of Life Sciences Prague, Faculty of Tropical AgriSciences \\ Email:kandakov@ftz.czu.cz
}

\section{Doi:10.5901/mjss.2015.v6n5p286}

\begin{abstract}
This study focuses on the field of citrus markets in the Lattakia region, the Syrian Arab Republic. Despite the high impact of citrus production on the livelihood of more than 40,000 families in the region, citrus farmers are not informed about expected prices and market trends. This information is crucial to making successful business decisions. The main aim of the paper is the assessment of Lattakia market price dynamics and to verify the use of regression and OLS models as tools of an Agricultural Marketing Information System (AMIS) for citrus price forecasting in the Lattakia region. To this end, five indicators were applied to the data set and two models for citrus wholesale price prediction on the Lattakia markets were tested in the paper. These indicators and models were applied to empirical data, obtained from an actual Marketing Information System in the Lattakia Region. The results showed high volatility in the prices between the markets and over different months and the regression model with an index of determination $R^{2}=0.90$ was identified as suitable for seasonal price predictions (short term forecasting), while the least square method was a good tool for annual price prediction (long term).
\end{abstract}

Keywords: Marketing Information System, AMIS, Lattakia, Syria, citrus fruits.

\section{Introduction}

Citrus is an important crop in the Syrian Arab Republic, as its production accounts for $5 \%$ of the gross national agricultural output and for 1,3\% of GDP (Bureau of Agricultural Statistics, 2009). Despite the high impact of citrus production on the livelihood of more than 40,000 families in the region, there is a substantial lack of information on market prices, demand, supply, and storage pricing, leading to high price variability.

Agricultural commodity markets are in general characterized by a high degree of volatility, due to relatively low elasticity in demand in the short run due in turn to the inability of production to respond to price changes, resulting in a lag in supply response to price changes which can cause the typical cyclical adjustments often referred to as the 'hog cycle', adding yet another degree of price variability. Further, in a market-oriented economy with perfect information a key variable in the food system is the price of the commodity (Goetz and Weber, 1986).

White and Dawson (2005) indicated that planting decisions are taken on the basis of expected prices at harvest time; hence forecasting of food prices will give farmers the opportunity to make informed decisions regarding planting in the future.

Farmers in the large numbers in the Lattakia region did not have information about the forecasts, they need to make production and marketing decisions that may have financial repercussions many months in the future (Allen,1994). Myers (2006) noted that since 1972 world commodity prices have risen at rates incomparable to any other quarter of the $20^{\text {th }}$ century. According to Shively (1996) increased price variability can have detrimental impacts on both consumers and producers of agricultural commodities, and since stocks are a large proportion of a farm household's portfolio in developing countries, and the level of market risks and the ability to bear risks may be correlated with income, low- 
income farmers are likely to be sensitive to price risks. Large price variations that cannot be anticipated create uncertainty that increases the risks for producers, traders, consumers and governments leading to sub-optimal decisions, but also causes concerns related to food security (FAO, 2003). Jones and Sanyang (2008) observed that, higher food prices affect price increases in downstream and upstream products and services. Alderman (1992) indicates that households with different income sources are affected diversely in the face of weather or pest-induced shocks, price increases or in the light of changes in policies and market conditions.

Increased food price instability/risk can lead agricultural producers to adopt risk-reducing strategies such as shifting towards more stable and lower value crops, reducing investment in new technologies or reduced use of purchased inputs (Lovendal et al., 2007). Ferris (1998) stated that market prices will be stable as long as demand and supply remain in equilibrium; once this equilibrium condition changes, prices will vary accordingly. In developing countries, access to information can truly empower decision-making in the sector, especially in rural areas. Millions of small producers, often illiterate, flounder in business transactions, and their vulnerability is sometimes exploited by consolidated contractors, commissioners and traders (Kotler, 2009). In the absence of an efficient marketing system, farmers are deprived of satisfactory income, eventually discouraging them from venturing into the cultivation of commercial crops such as fruits (Ervin,1982).

The first step in designing an effective Marketing Information System (MIS) is an analysis of the basic characteristics of actual markets prices (Bouchitté et al.,2012; Ramesh et al.,1996).

Another important step in the designing of an MIS is how to distribute, interpret and use the collected and processed information (Simon,1977;Rao,1985). The information should highlight changes in prices over time and it is generally more effective to draw trends reflecting rising and falling prices (Egg et al., 2003).

One of the solutions to improve the position of small citrus fruit producers in the Lattakia region is the creation of a functional citrus Market Information System (MIS). "MISes were seen as one way of increasing transparency (i.e., reducing information asymmetries among traders, small farmers, consumers and government) in the newly liberalized markets, thereby offering some protection to the more vulnerable actors in the system" (Tollens, 2009). An MIS is defined "as an organization or a group of organizations that: (1) collects data on market conditions, (2) processes and analyses the data to transform it into market information, and (3) disseminates market information products to different stakeholders using one or more channels" (Staatz et al.,2010).

To make an AMIS more economically sustainable and effective, one has to provide basic information on prices and market conditions free to all the target participant and the extension services (Dinar, 1996). The aim of this paper is to develop some models which could help farmers in the decision making process and improve the income of citrus producers on the one hand and increase their contribution to the national economy on the other hand.

Each market surveyed has its own trend lines showing how prices in that market varied over the year. Price fluctuation is a common feature of any functioning agricultural market. However, in underdeveloped countries it may be extremely large and volatile and may have a negative impact on consumer's food security, farmer's incomes and the country's economy (Addohet al.,2010).

Citrus prices in Lattkia have seasonal Characteristics and further fluctuation between the months and markets. The risk of price fluctuation among agricultural products has become one of the main risks faced by agricultural producers (Chuan, 2010).

Price fluctuation and changes were very important issues to the farmers in the Lattakia region, increases in the price of the commodity has generated significant discussion as to the causes and as to how to make appropriate decisions (World Bank, 2008; Sugden, 2009). Analysis of price volatility is necessary to develop bidding strategies and negotiation skills in order to maximize profit (Kuwornu, 2011). Price fluctuations make agriculture a risky business and especially high fluctuation has a negative impact on the income and economic situation of agricultural stake-holders (Grega, 2002).

This paper thus aims to analyze citrus fruit price volatility (of the "Autochthon" variety of lemon) on the Lattakia markets and tests a regression model with the incorporation of dummy variables and the Ordinary Least Squares (OLS) method to justify the creation and implementation of a functional MIS in the Syrian Arab Republic, which may help to reduce information asymmetries and improve the market position of small citrus producers in the Lattakia region, taking into consideration that no MIS has so far been created in the Lattakia region, and the need to encourage the Lattakia Agricultural Directorate to finance, create and implement an MIS in the region.

\section{Material and Methods}

The main aim of the paper is the assessment of Lattakia market price dynamics by applying five indicators to data set and 
to verify the use of regression and OLS models as tools of an Agricultural Marketing Information System (AMIS) for citrus price forecasting in the Lattakia region, the R. A. Syria. The purpose of the regression model is the forecasting of prices during the year and of price volatility. On the other hand, the OLS models should be able to predict average annual prices for several next years and provide a framework for the decision making processes of local farmers. There is a difference in the variables involved in both models. The regression model is based on the prices from previous years (2010-2013), while the OLS method involves other variables affecting Autochtone lemon prices. The regression model is suitable for short-term forecasting of price volatility during the year, but it is not able to react to changes in the determinants affecting the price. The OLS model is more robust and it is able to predict price changes allowing for changes in the variables involved.

In order to investigate the dynamics of the wholesale market prices in the region (Lattakia, Jablih, Al-Haffi, and AlQurdaha), data was obtained from the following official sources: Agricultural Extension Divisions, Official Agricultural Directorates, Directorates of Agricultural Affairs and Economic Departments of the Ministry of Agriculture. These data were obtained by one of the authors $(\mathrm{H}$. Sulaiman) during a visit to Syria. Data were available on the daily prices for several varieties of lemon traded at local markets. The data were not available in electronic form, so it was necessary to transfer them to MS Excel.

The Autochtone lemon variety is one of the most important varieties for 35,000 families in the Lattakia region. Annual production of it in Lattakia amounts to about 50,000 tonnes, in addition the Autochtone lemon is produced throughout the year, unlike the other varieties (CBS, 2014). But there is also large volatility in prices during the year caused by limited options in the timing and storage of the harvest. It is very important to analyse the prices and find appropriate models to provide important information (forecast prices) for the farmer and the entire market chain for Autochtone lemons.

\subsection{Five indicators were applied to the data set and used for the assessment of Lattakia market price dynamics:}

a. The Mean (arithmetic mean): the sum of all measurements in the period divided by the number of observations in the data set;

b. Volatility (variance): the dispersion of prices from their mean values (mathematical expectation of the average squared deviations from the mean).

c. The Coefficient of Variation: the ratio of the standard deviation over the mean as a measure of the dispersion of individual data. The higher the coefficient, the larger the dispersion and the higher the volatility of prices (Tothova,2011).

d. The Standard Deviation ( $\sigma)$ : this shows how much variation or dispersion exists from the average (mean), or expected value. A low standard deviation indicates that the data tends to be very close To the mean; high standard deviation indicates that the data is spread out over a large range of values.

e. The Moving Average: this a calculation to analyze data points by creating a series of averages of different subsets of the full data set (MA). A moving average is commonly used with time series data to smooth out short-term fluctuations and highlight longer-term trends or cycles. Moving Average techniques forecast prices by calculating an average of actual prices from a specified number of prior periods; each new forecast drops the prices in the oldest period and replaces it with the prices in the most recent period; thus, the data in the calculation "moves" over time.

$A t=\frac{D t+D t-1+D t-2+\cdots+D t-N+1}{N}(1)$

Where $\mathrm{N}=$ total number of periods in the average forecast for period $\mathrm{t}+1: \mathrm{Ft}+1=\mathrm{At}$

\subsection{Multiple Regression Model}

Farmers need only short term predicted prices, because citrus fruit is perishable and should be harvested during a period of \pm 15 days after ripening, so this predication can permit some spatial and temporary arbitrage. However, traders and exporters need short, mid and long term price predictions. So, to predict " Autochthon Lemon " prices (the equation's outputs) for: short-term (monthly prices), mid-term (quarterly) and long-term (annually) we chose Regression Analysis with the incorporation of dummy variables for the more detailed seasonal analysis (following the impact of particular months and quarters as these are the equation inputs). A regression function for seasonal Lemon prices was used as follows:

$$
\gamma=\beta_{0}+\beta_{1} * \text { Month }+\beta_{2} * Q_{T 1}+\beta_{3} * Q_{T 2}+\beta_{4} * Q_{T 3}+\beta_{5} * Q_{T 4}
$$


Where:

Y......... = price;

B0........ = coefficient for the intercept;

B1-5....... coefficient for the slope;

QT1-4.... = quarters.

Though the prices for the Autochthon Lemon variety on the Lattakia Market will be mentioned the Equation can be applied to the other citrus Markets (Al-Haffi, Al-Qurdaha and Jablih ) during the same period from 2010 to 2013.

\subsection{Ordinary Least Squares (OLS) Method}

To estimate the average annual prices of Autochtone lemons on the Lattakia market, the ordinary least squares method was used.

The OLS method minimizes the sum of the squares of residuals, and leads to a closed-form expression for the estimated value of the unknown parameters:

$$
\mathrm{Y}=(\mathrm{XT} X)-1 \mathrm{XT} y \quad \text { (3) }
$$

The estimator is unbiased and consistent if the errors have finite variance and are uncorrelated with the input variables (Robins, 1978).

$$
\left.X_{i} \in_{i}\right]=0 .
$$

In this model, $Y$ was defined as the price of Autochtone Lemons on the Lattakia market, while the $X$ vector consists of constants such as: X1 for production, X2 GDP growth, X3 annual price changes for the Autochtone lemon on the Jablih Market.

The form of the model is the following:

$$
\mathrm{y} 1 \mathrm{t}=f(x 1, x 2, x 3)
$$

After transformation to an econometric model:

$\mathrm{y} 1 \mathrm{t}={ }^{\chi} 1{ }^{*} \mathrm{x} 1 \mathrm{t}+{ }^{\chi} 2{ }^{*} \mathrm{x} 2 \mathrm{t}+{ }^{\chi} 3{ }^{*} \mathrm{x} 3 \mathrm{t}+\mathrm{u} 1 \mathrm{t}$

\section{Results}

In 2010 the amplitude of monthly price variation among the markets studied amounted to 11.4-76 S.P/kg for the Jablih and Lattakia markets respectively. In general, the Lattakia wholesale market showed the highest prices. Price peaks are evident during July - October, which coincides with non-harvesting periods of the other citrus varieties. Monthly prices in 2011 trended similarly as in 2010, with the highest prices during June - September. Amplitude variation in prices between markets was 9.6- 83 S.P/kg for the Qurdaha and Lattakia markets respectively. As usual, the Lattakia wholesale market had the highest prices and the Al-Qurdaha market the lowest ones. In 2012 and 2013 the weekly prices tended to a pattern, somewhat different than those monitored during 2010 and 2011.

The variation amplitude between markets was 9 - 100 S.P $/ \mathrm{kg}$ for the Qurdaha and Lattakia markets in 2012, respectively; and was extended towards the maximum prices more than towards the minimum prices. Table 1 of the annual trends in prices shows the high dispersion (volatility) of the prices around their mean, with an asymmetric distribution, fluctuating from the right side (decreasing prices) to the left one (increasing prices). The amplitude (standard deviations) ranged from 14.72 (Qurdaha 2013) to 20.77 (Lattakia 2013). Maximum prices were 2 or 6 times higher than minimum ones. These results are similar to Enders (2004) finding that: "In a volatile commodity price regime, there are periods of high volatility and periods of tranquility". Also, Negassaet al. (2003) found that "the volatility in commodity prices can change over a certain period of time." The prices of citrus varieties were calculated in Syrian pounds (SP).

Table 1. Mean, standard deviation, variance, minimum and maximum prices of Lemon Autochthon fruit, in the Lattakia region wholesale markets during (2010-2013).

\begin{tabular}{ccccccc}
\hline Market & Year & Mean & Standard deviation & Minimum SP / kg & Maximum SP / kg & Variance \\
\hline \multirow{3}{*}{ Jablih } & 2010 & 28.83 & 16.73 & 11.42 & 70.00 & 279.93 \\
& 2011 & 29.75 & 17.96 & 12.44 & 80.00 & 322.74 \\
& 2012 & 34.44 & 21.11 & 12.00 & 90.00 & 445.70 \\
& 2013 & 33.96 & 20.14 & 15.00 & 88.00 & 405.71
\end{tabular}




\begin{tabular}{lcccccc}
\multirow{5}{*}{ Qurdaha } & 2010 & 25.95 & 14.92 & 11.50 & 68.00 & 222.65 \\
& 2011 & 26.81 & 16.52 & 9.64 & 78.00 & 273.24 \\
& 2012 & 29.03 & 16.70 & 9.01 & 80.00 & 279.09 \\
\multirow{5}{*}{ Lattakia } & 2013 & 27.46 & 14.72 & 12.65 & 77.00 & 216.71 \\
& 2010 & 31.50 & 16.93 & 14.63 & 76.00 & 286.89 \\
& 2011 & 32.47 & 18.26 & 16.00 & 83.00 & 333.69 \\
& 2012 & 36.81 & 21.97 & 15.38 & 100.00 & 482.95 \\
Haffi & 2013 & 35.63 & 20.77 & 17.00 & 105.00 & 431.69 \\
& 2010 & 28.83 & 15.29 & 13.02 & 70.00 & 234.06 \\
& 2011 & 31.39 & 18.04 & 12.06 & 80.00 & 325.63 \\
& 2012 & 30.57 & 15.29 & 12.29 & 81.00 & 234.00 \\
& 2013 & 33.30 & 18.85 & 15.00 & 87.00 & 355.64 \\
\hline
\end{tabular}

Source: Own calculations, 2013

Figure1 below depicts annual trends and fluctuations in Autochthon Lemon mean prices in 2010-2013. The Jablih market is described by the linear regression equation $y=2.008 x+26.72$, indicating a positive (ascending) trend in lemon marketing prices. This linear equation predicts prices with a validity of $81.8 \%$ (deterministic coefficient $\mathrm{R}^{2}=0.818$ ). The Qurdaha market is described by the linear regression equation $y=0.675 x+25.62$, indicating an ascending trend in lemon marketing prices. This linear equation predicts prices with a validity of $44.8 \%$ (deterministic coefficient $\mathrm{R}^{2}=0.448$ ), which suggests a considerable volatility in prices on the Qurdaha market. The Lattakia market is described by the linear regression equation $y=1.673 x+29.92$, indicating a positive trend in lemon marketing prices. This linear equation predicts prices with a validity of $73.2 \%$ (deterministic coefficient $R^{2}=0.732$ ). The Haffi market is described by the linear regression equation $y=1.259 x+27.87$, indicating a positive trend in lemon marketing prices. This linear equation predicts prices with a validity of $76.6 \%$ (deterministic coefficient $R^{2}=0.766$ ).

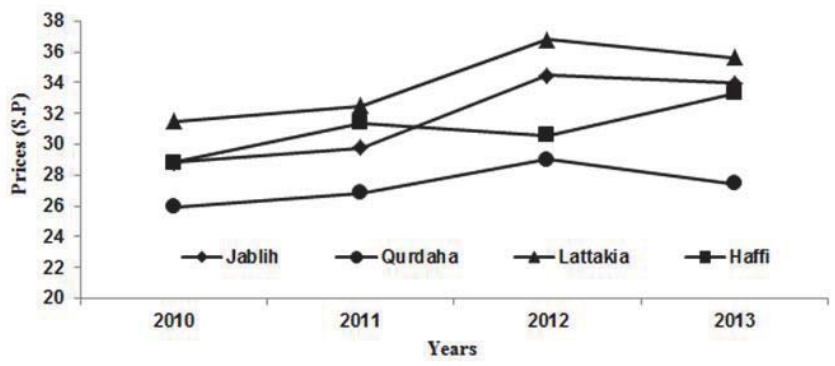

Figure 1. Annual trends and fluctuation for Lemon Autochthon mean prices in Lattakia region wholesale markets during (2010-2013).

Source: Own calculations, 2013

In Figure 2 Autochthon Lemon price variance throughout 2010-2013 in the Lattakia region represents significant differences in prices between years and markets, which ranged from 216.7 to 482.9 S.P. for the Qurdaha market (2013) and the Lattakia market (2012) respectively. 


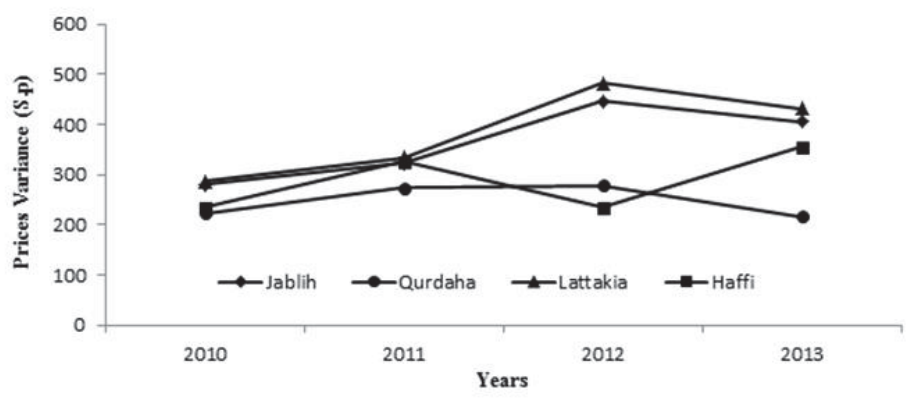

Figure 2. Annual fluctuation for Lemon Autochthon variance in prices 2010-2013

Source: Own calculations, 2013

\subsection{Moving Average of Autochthon lemon prices on the Lattakia market.}

Autochthon Lemon prices vary considerably during the year on the Lattakia market. Trees of Autochthon Lemons produce fruit constantly, and the prices in the summer are two - three times higher than in winter months. A moving average is calculated for 2, 4 and 6 monthly intervals, to smooth out differences and more easily recognize trends; the longer the interval, the less irregularities (peaks and valleys). So, in figure 3, the curve of the 6 month interval shows a clearly ascendant trend in Autochthon lemon prices during 2010-2013.

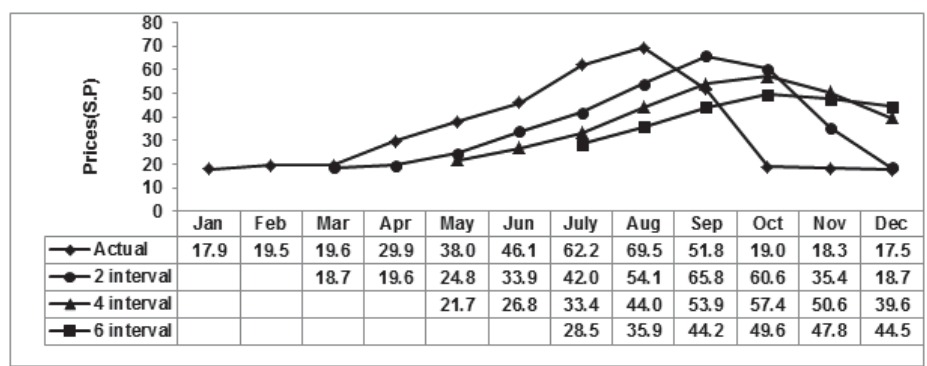

Figure 3. Moving Average of lemon Autochthon prices in the Lattakia market during 2010-2013

Source: Own calculations, 2013

\subsection{Prediction of Autochthon Lemon variety prices in the Lattakia market}

The development of Autochthon lemon prices over the 48 months (from the year 2010 to 2013) based on input data was observed. Explanatory variables are: 1 . The months (1-12), 2. The quarters (1-4), needed to characterize and predict prices.

The regression model describing the dynamics of the market prices was found to be:

$\gamma=\beta_{0}+\beta_{1} *$ Month $+\beta_{2} * Q_{T 1}+\beta_{3} * Q_{T 2}+\beta_{4} * Q_{T 3}+\beta_{5} * Q_{T 4}$

An Index of determination of $\mathrm{R}^{2}=0,906$ was detected, which indicates that $90.6 \%$ of Lemon Autochthon monthly price changes can be sufficiently explained by the model. Thus the Marketing Information System will be able to provide statistical data to its users about expected prices in subsequent months or years by using the following formula:

Price $=16.167+0.141 *$ Month $+0 * \mathrm{QT} 1+18.553^{*} \mathrm{QT} 2+41.294^{*} \mathrm{QT} 3-2^{*} \mathrm{QT} 4$

The data on Autochthon lemon monthly prices were statistically processed by the use of regression analysis with incorporation of Dummy (logical) variables (Table 2) as the best suited model for seasonal analysis of Autochthon lemon prices variability from 2010 to 2013. 
Table 2. Regression statistics with incorporation of dummy (logical) variables

\begin{tabular}{|l|c|}
\hline Multiple R & 0.9518884 \\
\hline R Square & 0.9060915 \\
\hline Adjusted R Square & 0.8741 \\
\hline Standard Error & 5.9873845 \\
\hline Observations & 48 \\
\hline
\end{tabular}

\begin{tabular}{|l|c|c|c|c|c|}
\hline \multicolumn{7}{|c|}{ ANOVA } \\
\hline & Df & SS & MS & F & Significance F \\
\hline Regression & 5 & 14873.38104 & 2974.676 & 103.7231 & $1.64 \mathrm{E}-22$ \\
\hline Residual & 43 & 1541.49726 & 35.84877 & & \\
\hline Total & 48 & 16414.8783 & & & \\
\hline
\end{tabular}

\begin{tabular}{|c|c|c|c|c|c|c|c|c|}
\hline & 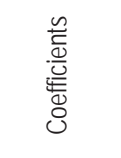 & 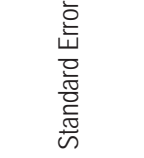 & 莺 & 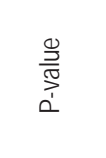 & $\begin{array}{l}\text { ㅇํㅇ } \\
\overline{0} \\
\text { 亏े }\end{array}$ & 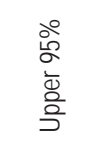 & 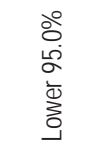 & $\begin{array}{l}\text { ठ̊ } \\
\text { ஸू } \\
\text { षे } \\
\frac{0}{2}\end{array}$ \\
\hline Intercept & 16.167069 & 2.154283872 & 7.504614 & 2.41E-09 & 11.82254 & 20.5116 & 11.82254 & 20.5116 \\
\hline Month & 0.1416882 & 0.064295047 & 2.203719 & 0.032948 & 0.012025 & 0.271352 & 0.012025 & 0.271352 \\
\hline Months 1-3 & 0 & 0 & 65535 & 0 & 0 & 0 & 0 & 0 \\
\hline Months 4-6 & 18.553269 & 2.451938062 & 7.566777 & 1.96E-09 & 13.60846 & 23.49807 & 13.60846 & 23.49807 \\
\hline Months 7-9 & 41.294871 & 2.474593763 & 16.68754 & $2.13 \mathrm{E}-20$ & 36.30438 & 46.28536 & 36.30438 & 46.28536 \\
\hline Months $10-12$ & -2.001027 & 2.511899217 & -0.79662 & 0.430049 & -7.06675 & 3.0647 & -7.06675 & 3.0647 \\
\hline
\end{tabular}

Source: Author's calculations 2013

To verify explanatory power of the model and to estimate Autochthon lemon prices we deployed the data into the regression equation in order to determine the expected (theoretical) price on the Lattakia market compared with the empirical price: (Table 3 ).

Table 3. Lemon "Autochthon" variety monthly prices with incorporation of Dummy (2010 - 2013)

\begin{tabular}{|l|c|c|c|c|c|c|c|c|}
\hline & & QT1 & QT2 & QT3 & QT4 & & & \\
\hline & Month & Months 1-3 & Months 4-6 & Months 7-9 & Months 10-12 & Empirical price & Predicted price & Residual \\
\hline January & 1 & 1 & 0 & 0 & 0 & 17.13 & 16.3 & 0.83 \\
\hline February & 2 & 1 & 0 & 0 & 0 & 21.50 & 16.44 & 5.06 \\
\hline March & 3 & 1 & 0 & 0 & 0 & 19.03 & 16.58 & 2.45 \\
\hline April & 4 & 0 & 1 & 0 & 0 & 26.00 & 35.27 & -9.27 \\
\hline May & 5 & 0 & 1 & 0 & 0 & 34.00 & 35.41 & -1.41 \\
\hline June & 6 & 0 & 1 & 0 & 0 & 42.25 & 35.55 & 6.7 \\
\hline July & 7 & 0 & 0 & 1 & 0 & 55.75 & 58.43 & -2.68 \\
\hline August & 8 & 0 & 0 & 1 & 0 & 60.00 & 58.57 & 1.43 \\
\hline September & 9 & 0 & 0 & 1 & 0 & 50.00 & 58.71 & -8.71 \\
\hline October & 10 & 0 & 0 & 0 & 1 & 17.00 & 15.56 & 1.44 \\
\hline November & 11 & 0 & 0 & 0 & 1 & 18.00 & 15.7 & 2.3 \\
\hline December & 12 & 0 & 0 & 0 & 1 & 17.30 & 15.84 & 1.46 \\
\hline January & 13 & 1 & 0 & 0 & 0 & 17.6 & 17.98 & -0.38 \\
\hline February & 14 & 1 & 0 & 0 & 0 & 18.5 & 18.12 & 0.38 \\
\hline March & 15 & 1 & 0 & 0 & 0 & 19.5 & 18.26 & 1.24 \\
\hline April & 16 & 0 & 1 & 0 & 0 & 28 & 36.95 & -8.95 \\
\hline may & 17 & 0 & 1 & 0 & 0 & 36 & 37.09 & -1.09 \\
\hline June & 18 & 0 & 1 & 0 & 0 & 46 & 37.23 & 8.77 \\
\hline July & 19 & 0 & 0 & 1 & 0 & 58 & 60.11 & -2.11 \\
\hline
\end{tabular}




\begin{tabular}{|l|c|c|c|c|c|c|c|c|}
\hline August & 20 & 0 & 0 & 1 & 0 & 63 & 60.25 & 2.75 \\
\hline September & 21 & 0 & 0 & 1 & 0 & 50 & 60.39 & -10.39 \\
\hline October & 22 & 0 & 0 & 0 & 1 & 17.5 & 17.24 & 0.26 \\
\hline November & 23 & 0 & 0 & 0 & 1 & 18.25 & 17.38 & 0.87 \\
\hline December & 24 & 0 & 0 & 0 & 1 & 17.25 & 17.52 & -0.27 \\
\hline January & 25 & 1 & 0 & 0 & 0 & 18.25 & 19.66 & -1.41 \\
\hline February & 26 & 1 & 0 & 0 & 0 & 19 & 19.8 & -0.8 \\
\hline March & 27 & 1 & 0 & 0 & 0 & 20 & 19.94 & 0.06 \\
\hline April & 28 & 0 & 1 & 0 & 0 & 32 & 38.63 & -6.63 \\
\hline May & 29 & 0 & 1 & 0 & 0 & 40 & 38.77 & 1.23 \\
\hline June & 30 & 0 & 1 & 0 & 0 & 48 & 38.91 & 9.09 \\
\hline July & 31 & 0 & 0 & 1 & 0 & 70 & 61.79 & 8.21 \\
\hline August & 32 & 0 & 0 & 1 & 0 & 80 & 61.93 & 18.07 \\
\hline September & 33 & 0 & 0 & 1 & 0 & 55 & 62.07 & -7.07 \\
\hline October & 34 & 0 & 0 & 0 & 1 & 22.5 & 18.92 & 3.58 \\
\hline November & 35 & 0 & 0 & 0 & 1 & 19 & 19.06 & -0.06 \\
\hline December & 36 & 0 & 0 & 0 & 1 & 18 & 19.2 & -1.2 \\
\hline January & 37 & 1 & 0 & 0 & 0 & 18.5 & 21.34 & -2.84 \\
\hline February & 38 & 1 & 0 & 0 & 0 & 19 & 21.48 & -2.48 \\
\hline March & 39 & 1 & 0 & 0 & 0 & 20 & 21.62 & -1.62 \\
\hline April & 40 & 0 & 1 & 0 & 0 & 33.5 & 40.31 & -6.81 \\
\hline May & 41 & 0 & 1 & 0 & 0 & 42 & 40.45 & 1.55 \\
\hline June & 42 & 0 & 1 & 0 & 0 & 48 & 40.59 & 7.41 \\
\hline July & 43 & 0 & 0 & 1 & 0 & 65 & 63.47 & 1.53 \\
\hline August & 44 & 0 & 0 & 1 & 0 & 75 & 63.61 & 11.39 \\
\hline September & 45 & 0 & 0 & 1 & 0 & 52 & 63.75 & -11.75 \\
\hline October & 46 & 0 & 0 & 0 & 1 & 19 & 20.6 & -1.6 \\
\hline November & 47 & 0 & 0 & 0 & 1 & 18 & 20.74 & -2.74 \\
\hline December & 48 & 0 & 0 & 0 & 1 & 17.5 & 20.88 & -3.38 \\
\hline
\end{tabular}

Source: Author's calculations 2013

Figure 4 shows empirical and predicted monthly "Autochthon" lemon prices during the period 2010-2013 on the Lattakia market.

Figure 4. Empirical monthly prices of Lemon Autochthon as compared with those predicted

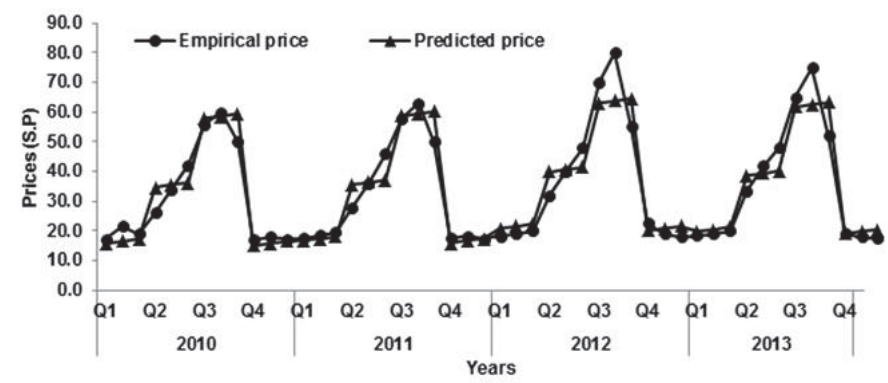

Source: Own calculations, 2013

\subsection{Prediction by OLS model}

Here, the ordinary least squares method was applied, using the Gretl software package to estimate the price development of Autochtone lemons on the Lattakia market. 
Table 4. Ordinary least square model using observations data from 2003-2013 $(T=11)$

Dependent variable: $y$

\begin{tabular}{|c|c|c|c|c|c|}
\hline & Coefficient & Std. Error & t-ratio & p-value & \\
\hline const & -6.813 & 1.44493 & -4.7151 & 0.00217 & *** \\
\hline X1 & 0.0022155 & $9.72763 \mathrm{e}-05$ & 22.7753 & $<0.00001$ & *** \\
\hline X2 & -0.122986 & 0.0190239 & -6.4648 & 0.00035 & *** \\
\hline X3 & 0.0641669 & 0.027968 & 2.2943 & 0.05546 & $*$ \\
\hline
\end{tabular}

\begin{tabular}{|l|c|l|c|}
\hline Mean dependent var & 27.99636 & S.D. dependent var & 5.552623 \\
\hline Sum squared resid & 1.566119 & S.E. of regression & 0.473002 \\
\hline R-squared & 0.994920 & Adjusted R-squared & 0.992743 \\
\hline $\mathrm{F}(3,7)$ & 457.0215 & P-value(F) & $2.17 \mathrm{e}-08$ \\
\hline Log-likelihood & -4.887205 & Akaike criterion & 17.77441 \\
\hline Schwarz criterion & 19.36599 & Hannan-Quinn & 16.77114 \\
\hline rho & -0.073641 & Durbin-Watson & 2.031205 \\
\hline
\end{tabular}

Where the $\mathrm{X} 1$ is production, $\mathrm{X} 2 \mathrm{GDP}$ growth, $\mathrm{X} 3$ the annual price change of Autochtone lemons on Jablih Market.

The coefficient of determination is 0.994 and the adjusted coefficient of determination is 0.9927 there are only 0.6 $\%$, resp. $0.73 \%$ factors not involved in the equation. There is strong relationship between endogenous and exogenous variables. All chosen variables are significant at a level of $\alpha=0.1$, except $X 3$ at a level of $\alpha=0.05$.

White's test was conducted to test the homoscedasticity of the model. Heteroscedasticity was rejected according to the test. The Durbin-Watson test was made to detect autocorrelation in the residuals. The result of the test rejects autocorrelation. The value 0.0022155 for the $\mathrm{X} 1$ parameter shows a positive relationship between the price $(\mathrm{Y})$ and production; if the production rises by about one tonne of Autochtone lemons in Lattakia, than the price will increase by about 0.0022155 of a Syrian pound. There is a negative correlation between the annual GDP growth in \% and Autochtone lemon prices in Lattakia. If the GDP increases by about one percent, the price will decrease by about 0.122986. It is necessary to note that this fact could be caused by the current political situation in Syria when GDP decreased yearly by more than $20 \%$ in last two years. There was an estimated parameter of 0.0641669 for the percentage annual price change of Autochton lemons at the Jablih market (X3). This parameter shows a positive correlation between the prices at Lattakia and Jablih markets. If the price changes about one percent at the Jablih market, than the price will increase by about 0.0641669 of a Syrian pound. This result is in compliance with economy theory.

To predict prices estimated data on Autochton lemon prices on the Jablih market from the Jablih AMIS were used, and estimated GDP growth based on CBS data. The production of Autochtone lemons in Lattakia was estimated according to a single linear regression which was found to be the most appropriate with an adjusted coefficient of correlation of 0.9775 . It is judged that prices will exceed the figure of 40 Syrian pounds per one kilogram in 2018. It is necessary to note that in regard of the security situation in Syria the estimated GDP can be biased by error.

Table 5. Empirical and Predicted annual Prices of Autochtone Lemons in Lattakia 2003-2013

\begin{tabular}{|c|c|c|c|c|c|}
\hline \multirow[t]{2}{*}{ Year } & \begin{tabular}{|} 
Lemon Autochtone price on \\
the Latakia Market (Annual in \\
SYP/Kg)
\end{tabular} & $\begin{array}{c}\text { Production of Autochtone } \\
\text { lemons in Latakia (annual in } \\
\text { tonnes) }\end{array}$ & $\begin{array}{c}\text { GDP Growth in } \\
\text { Syria (annual in \%) }\end{array}$ & $\begin{array}{l}\text { LeomonAutochtone price } \\
\text { change in \% on the Jablih } \\
\text { Market (Annual in SYP/Kg) }\end{array}$ & \multirow[t]{2}{*}{$\begin{array}{c}\text { Theoretical } \\
\text { values }\end{array}$} \\
\hline & $\mathrm{Y}$ & X1 & $\mathrm{X} 2$ & $\mathrm{X} 3$ & \\
\hline 2003 & 21 & 12574 & 0.9 & 2.78 & 21.11 \\
\hline 2004 & 21.8 & 12895 & 2.3 & 5.26 & 21.81 \\
\hline 2005 & 23 & 13649 & 2.8 & 3.80 & 23.33 \\
\hline 2006 & 24.5 & 13854 & 3.5 & 5.95 & 23.83 \\
\hline 2007 & 25.25 & 14542 & 4.3 & 2.33 & 25.03 \\
\hline 2008 & 26 & 15235 & 5.1 & 2.27 & 26.46 \\
\hline 2009 & 30 & 16598 & 5 & 18.52 & 30.53 \\
\hline 2010 & 31.5 & 17103 & 3.2 & 6.35 & 31.09 \\
\hline 2011 & 32.47 & 17434 & -2 & 3.09 & 32.26 \\
\hline 2012 & 36.81 & 17945 & -21.8 & 13.62 & 36.50 \\
\hline 2013 & 35.63 & 18123 & -22.5 & -1.41 & 36.01 \\
\hline
\end{tabular}




\begin{tabular}{|l|l|l|l|l|l|}
\hline 2014 \\
2015 \\
2016 & & 19140 & -5.8 & -3.17 & 36.10 \\
2017 & 19747 & 2.9 & 2.43 & 36.73 \\
2018 & 20354 & 6.2 & 6.37 & 37.93 \\
\hline
\end{tabular}

Source: own calculation, based on data of the Agricultural Directorate in Lattakia and CBS.

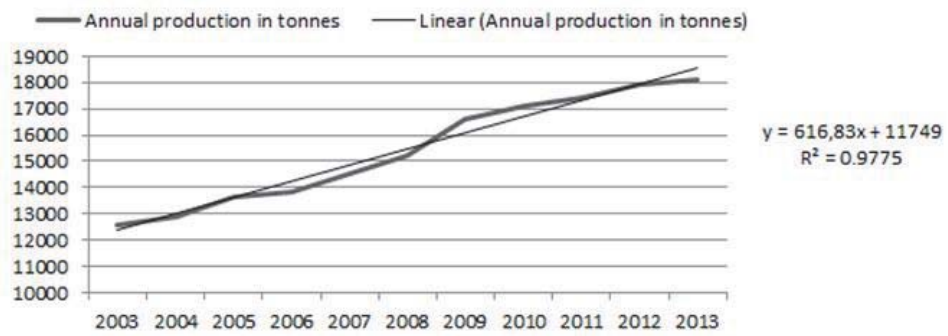

Figure 5. Annual production of Autochton Lemons in Lattakia in tonnes 2003-2013

Source: own calculation, based on data of Agricultural Directorate in Lattakia and CBS.

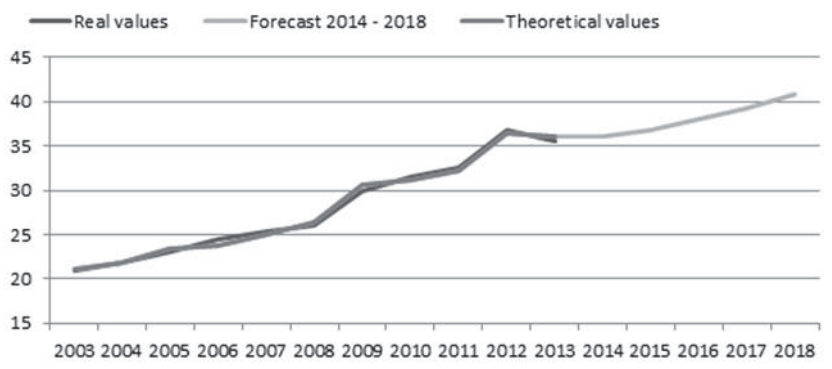

Figure 6. Empirical (real) annual prices of Autochtone Lemons compared with predicted (theoretical) prices at Lattakia Market 2003 - 2013 in SYP/Kg

Source: own calculation, based on data of Agricultural Directorate in Lattakia and CBS

\section{Conclusion}

This research answers the following questions: are the regression and OLS models suitable as part of an Agricultural Marketing Information System (AMIS) which could possibly be implemented in the citrus markets in the Lattakia region in Syria? To answer this question models for Autochthon lemon price forecasting were developed. These models were tested to see if they were able to predict a) the price during the year with its seasonal volatility - a regression model, b) average annual prices - an OLS model. The fluctuation in prices recorded above could be partially removed by the reduction of information asymmetry in the region, however, a functional AMIS would be necessary to improve the position of farmers in the markets and help them in decision making and smoothing income volatilities.

As shown, Autochthon lemon prices differed across the wholesale markets studied, where the Lattakia wholesale market showed the highest prices and the Al-Qurdaha market the lowest ones. The differences between the markets have also increased during the period of 2010 -2013. The differences are influenced by many factors such as a lack of market information and on-going information asymmetry, the presence of large retail chains in Lattakia city, variations in the purchasing power of the population, the availability of transport to other cities and the annual rate of inflation due to 
currency depreciation. Also the different harvesting periods of various fruit varieties affect prices, as a result of surpluses in supply in January - April and a shortage of supply in the summer periods. This is especially relevant to Lemon varieties, which recorded the highest dispersion of citrus prices; standard deviations ranged from 14.72 (Qurdaha market, 2013) to 20.77 (Lattakia market, 2013).

A marketing information system linked to e-commerce platforms could lead to improved and more efficient management of the market for producers and intermediaries, as well as wholesale clientele and could contribute to accelerated agricultural development. Apart from the above mentioned, examples from other markets confirm that an AMIS can be integrated into e-commerce, and may form a useful tool for agribusiness companies and farmers, who would like to practice agricultural e-commerce in the Lattakia region. Decentralized agricultural production management linked to markets with agricultural products via internet based systems with low initial capital requirements can be considered a useful tool for the future postwar reconstruction of Syria.

\section{Acknowledgements}

Research was financially supported by the Internal Grant Agency of the Faculty of Tropical AgriSciences number 20155016.

\section{References}

Addoh, S. L. (2010). Strengthening the capabilities of agricultural organization networks through analysis of the evolution of local grain prices in Burkina, Mali, and Niger, during the period 2001-2010 and its repercussions for warrantee in Niger. Montreuil: Africa Verte International.

Alderman, H.(1992). Incomes and Food Security in Ghana.Cornell Food and Nutrition policy program. [Online] Available: http://www.cfnpp.cornell.edu/images/wp26.pdf. (Accessed: 12 October 2013).

Allen, P.G.(1994). Economic forecasting in agriculture. International Journal of Forecasting,10 (1994): 81-135.

Bouchitté, A., Dardel, S. (2012). Europe Aid: Agricultural Markets and Small-scale Producers: Access and Risk Management Tools. [Online] Available:http://ec.europa.eu/europeaid/infopoint/publications/europeaid/documents/269a_en.pdf (Accessed: 17 September 2013).

Bureau of Agricultural Statistics (2009).STAT. Syrian Arab Republic.(Accessed on 14 March 2013).

Chuan, W., Junye, Z., and Min, H. (2010). Measurement of the Fluctuation Risk of the China Fruit Market Price based on VaR. International Conference on Agricultural Risk and Food Security, 1: 212-218.

Citrus Board Directorate.2014.CBD.Damascus, Syria Arab Republic. (Accessed on 11 March 2014).

Dinar, A. (1996). Extension Commercialization: How much to charge for extension services. American Journal of Agricultural Economics,78(1): 1-12.

Egg, J., Galtier, F. (2003). From price reporting systems to variable geometry oriented market information services. Cirad/Inra, 2: 52-70.

Enders, W. (2004). Applied econometrics time series. (2nded). Birmingham: Alabama University Journal.

Ervin, C.A., Ervin, D. E.(1982). Factors affecting the use of soil conservation practices: hypotheses, evidence and policy implications. Journal of Land Economics, 58(3): 277-292.

Ferris, S., P. and Kaganzi, E. (2008). Making Market Information Services Work Better for the Poor in Uganda. Washington, DC: CAPRi.

Food and Agriculture Organization of the United Nations (FAO). (2003).Trade Reforms and Food Security. Rome.

Goetz, S. and Weber, M. T. (1986). Fundamentals of Price Analysis in Developing Countries' Food Systems: A Training Manual to Accompany the Microcomputer Software Program "MSTAT". Department of Agricultural Economics. Michigan State University Journal.

Grega, L. (2002). Price stabilization as a factor of competitiveness of agriculture. Journal of AGRIC. ECON, 48(7): 281-284.

Jones, M. P. and Sanyang, S. (2008). Multiple Pressures of Soaring Food Prices and Food Security in Africa. Current Science, 95(9): $1317-1319$.

Kotler, P., Armstrong, G. (2009). Marketing: An Introduction.(9th ed.). Englewood Cliffs, NJ.: Prentice-Hall.

Kuwornu, J.K.M., Bonsu, A.M, Ibrahim, H. (2011). Analysis of Food stuff Price Volatility in Ghana: Implications for Food Security. European Journal of Business and Management, 3(4): 100-118.

Lovendal, C. R., Jakobsen, K. T., and Jacque, A. (2007). Food Prices and Food Security in Trinidad and Tobago. Agricultural Development Economics Division. Food and Agricultural Organization. ESA Working paper No. 07-27.

Myers, R. J. (2006). On the Cost of Food Price Fluctuations in Low-Income Countries. Journal of Food Policy, 31(4): 288-301.

Negassa, A., Meyers, R. \& Gabre, E. (2003). Analyzing grain market efficiency in developing countries: Review of existing methods and extensions to the parity bounds model. Washington, DC: International Food Policy Research Institute.

Ramesh, B., Singh, Y. P., Sachdeva, R. K.(1996). Establishing a management information system: Improving agricultural extension. Food and Agricultural Organization.Reference manual. Rome, Italy. [Online] Available: http://www.fao.org/docrep/w5830e/ w5830e0k.htm (Accessed on 15 October 2013).

Rao, C. SS. (1985). Agricultural extension management system in India: Past, present and modalities in future. Indian Journal of 
Extension Education, 21(1 \& 2): 32-35.

Robbins, H., Lai, T.L., Wei, C.Z. (1978). Strong consistency of least squares estimates in multiple regression. PNAS, 75, 3034-3036.

Simon, H. A. (1977). The new science of management decision. Journal of Administrative Science Quarterly, 22(2): $342-351$.

Shively, G. E. (1996). Food Price variability and Economic Reform: An ARCH Approach for Ghana. American Journal of Agricultural Economics, 78(1): 126-136.

Staatz, J. M., Kizito, A. M., Weber, M.T. and Dembélé, N.N. (2010). Pathways from Improved Market Information to Better Market Performance: Implications for the Evaluation of Investments in Agricultural Market Information Systems. Cahiers agricultures: Special issue on Market Information Systems,19: 387-388.

Sugden, C. (2009). Responding to High Commodity Prices. Asian-Pacific Economic Literature, 23(1): 79-105.

Tollens, E.F. (2009). Market Information Systems in sub-Sahara Africa: Challenges and Opportunities. International Agricultural Economists Conference, Gold Coast, Australia.

Tothova, M. (2011). Main Challenges of Price Volatility in Agricultural Commodity Markets. Methods to Analyse Agricultural Commodity Price Volatility, DOI 10.1007/978-1-4419-7634-5_2, @ Springer Science +Business Media 10: 13-29.

White, B. and Dawson, P. J. (2005).Measuring Price Risk on UK Arable Farms. Journal of Agricultural Economics, 56(2): 239-252.

World Bank, (2008).The challenges of high food and fuel prices, presented to the Commonwealth Finance Meeting, Saint Lucia.Poverty Reduction and Economic Management Network. London: Commonwealth Secretariat. 